\title{
Potential Ex-vivo Anti-inflammatory, Cardioprotective Properties and Phytochemical Properties of Leaves of Mussaenda Roxburghii Hook
}

\author{
Farzana Akther Sumi ${ }^{1}$, Biswajit Sikder ${ }^{1}$, Prawej Ansari ${ }^{1}$, Md. Reyad-ul- Ferdous ${ }^{1,2,{ }^{*}, \text { Anaytulla }}{ }^{1}$, \\ Mustafe Khalid Mohamed ${ }^{1}$, Md. Mustarek Uddin Meemo ${ }^{1}$ \\ ${ }^{1}$ Department of Pharmacy, North South University, Dhaka, Bangladesh \\ ${ }^{2}$ Department of Pharmacy, Progati Medical Institute, Dhaka, Bangladesh
}

Email address:

rockyreyad@yahoo.com (Md. R. Ferdous)

To cite this article:

Farzana Akther Sumi, Biswajit Sikder, Prawej Ansari, Md. Reyad-ul- Ferdous, Anaytulla, Mustafe Khalid Mohamed, Md. Mustarek Uddin Meemo. Potential Ex-vivo Anti-inflammatory, Cardioprotective Properties and Phytochemical Properties of Leaves of Mussaenda Roxburghii Hook. American Journal of Clinical and Experimental Medicine. Special Issue: Herbal Remedies as Alternative to Future Drugs Development and Treatment. Vol. 3, No. 5-1, 2015, pp. 1-6. doi: 10.11648/j.ajcem.s.2015030501.11

\begin{abstract}
Background: mussaenda roxburghii hook. Belongs to family rubiaceae, is a perennial shrub moist area of valley and grows in the foothills. Objective: the present investigation was carried out to phytochemicals and pharmacological activity such anti-inflammatory, cardioprotective properties of methanolic crude extract $\&$ its fractions such as dcm extract (fraction 1), ethyl acetate extract (fraction2). Materials and methods: residual methanolic extract (fraction 3) of mussaenda roxburghii leaves which were obtained by solvent-solvent extraction process from crude methanolic extract of mussaenda roxburghii. Anti-inflammatory activity was measured by observing the mean inhibition of protein denaturation. Cardioprotective activity was evaluated by thrombolytic assay. Phytochemical screenings have done by using usual procedures. Results: an ex-vivo antiinflammatory test demonstrated that; mean inhibition of protein denaturation of 1000/kg of crude methanolic extract of leave of $m$. Roxburghii was $17.399 \%$. Cardioprotective properties of different extracts of $\mathrm{m}$. Roxburghii was demonstrated which revealed that after treatment of clot with mother methanolic extract, dcm extract (fraction 1), ethyl acetate extract (fraction 2), residual methanolic extract (fraction3) of leaves and methanolic extract of root \% clot lysis was $30.56 \%, 27.61 \%, 46.35 \%, 26.02 \%, 49.90 \%$ respectively. Different tests with crude extracts showed that different types of alkaloids, carbohydrates, tannins were present in the leaves of $m$. Roxburghii. Conclusion: in these investigations demonstrates that different extracts of $m$. Roxburghii has significant pharmacological activities.
\end{abstract}

Keywords: Ex-vivo Anti-inflammatory, Cardioprotective Properties, Phytochemicals Investigation, Mean Inhibition of Protein Denaturation

\section{Introduction}

The goals of using plants as sources of therapeutic agents are to isolate bioactive compounds for direct use as drugs. Eg: taxol, digitoxin, morphine, digoxin, vinblastine \& vincristine as well as reserpine, produce bioactive compounds of novel or known structures as lead compounds for semisynthesis to produce patentable entities of higher activity and/or lower toxicity.eg: taxotere, teniposide etc ${ }^{[1]}$. Mussaenda roxburghii hook. Belongs to rubiaceae; is a perennial shrub grows in the foothills and moist areas of valley. Roots are traditionally used in treatment of cuts, jaundice, wounds, boils and skin diseases etc $^{[2,3]}$. Leaves are used in the ailments of bone fracture ${ }^{[4]}$. The paste obtained from leaf of this plant is applied to treat boils ${ }^{[5]}$. Previous phytochemical investigation led to isolation of a new iridoid, shanzhiol which showed mild antibacterial activity against both staphylococcus aureus and escherichia coli with a mic of $100 \mu \mathrm{g} / \mathrm{ml}$ by the broth dilution method ${ }^{[6]}$. As part of our ongoing research with medicinal plant of bangladesh ${ }^{[9,10]}$ the present study has been undertaken to evaluate the preliminary cytotoxicity 
and antimicrobial activity of m. Roxburghii as well as to find out logical evidence for its folk uses and for discovery of new drug candidates.

\section{Materials and Methods}

\subsection{Plant Materials}

The leaves of mussaenda roxburghii were collected from chittagong, bangladesh, in november 2013. A voucher specimen for this plant has been maintained in bangladesh national herbarium, dhaka, bangladesh (accession no. Mfk137. Ctg uh). The sun dried and powdered (500 gm) leaves of $p$. Cereifera was macerated in 2.51 of methanol for 7 days and then filtered through a cotton plug followed by whatman filter paper number 1 . All extracts were concentrated with a rotary evaporator at reduced pressure and low temperature $\left(40-45^{\circ} \mathrm{c}\right)$. The concentrated methanolic extracts (me) were partitioned by modified kupchan method [7] and described by md. Reyad-ulferdous $^{[9]}$ the resultant partitionates which are pet-ether (pesf), chloroform (csf), carbon tetrachloride (ctcsf), and aqueous (aqsf) soluble fractions were used for the experimental processes.

\subsection{Ex-vivo anti-inflammatory Activity Study}

Inhibition of albumin denaturation was conducted for evaluation of ex-vivo anti-inflammatory activity. The present study was developed by certain modification of the method claimed by mizushima y and kobayashi $\mathrm{m}^{[8]}$ on the basis of in-vitro determination of the protein maturation caused by the control group and comparing it with the positive and test groups. The more the inflammatory action, the more it will cause the protein maturation and the measured absorbance will be higher. The reaction mixture was consisting of test extracts at different concentrations and $1 \%$ aqueous solution of bovine albumin fraction. Reaction mixture ph was adjusted using small amount of $1 \mathrm{n} \mathrm{hcl}$. Aspirin was taken as standard drug. The samples were incubated at $37^{\circ} \mathrm{c}$ for 20 min and then heated at $57^{\circ} \mathrm{c}$ for $30 \mathrm{~min}$. After cooling the samples, the turbidity was measured spectrophotometrically at $660 \mathrm{~nm}$. The experiment was performed in triplicate. \% inhibition of protein denaturation was calculated as follows: percentage inhibition $=($ abs control - abs sample $) /$ abs control $\times 100$

\subsection{Cardio-protective Activity Assay}

The cardio-protective activity was evaluated by thrombolytic activity assy. The thrombolytic activity of all extracts was evaluated by the method describe by daginawala [11] and modified by kawsar ${ }^{[12]}$ using streptokinase (sk) as the standard as well as described by reyad-ul-ferdous $\mathrm{m}^{[9]}$. $0.1 \mathrm{gm}$ extract was suspended in $10 \mathrm{ml}$ distilled water and the suspension was shaken vigorously on a vortex mixer. The suspension was kept overnight and decanted to remove the soluble supernatant, by using a filter. $100 \mu \mathrm{l}$ of this aqueous preparation of herbs was added to the alpine tubes containing the clots to check the thrombolytic activity. 10 alpine tubes were taken and each eppendrof tube containing clot was properly labeled and venous blood drawn from the healthy volunteers. That was transferred in 10 different pre weighed sterile alpine tube $(0.5 \mathrm{ml} /$ tube $)$ and incubated at $37^{\circ} \mathrm{c}$ for 45 minutes. Aspirated washout without disturbing the clot formed. Water was also added to one of the tubes containing clot and this serves as a negative thrombolytic control. All the tubes are than incubated at $37^{\circ} \mathrm{c}$ for 90 minutes and observed for clot lysis. After incubation, fluid obtained was removed and tubes were again weighed to observe the difference in weight after clot disruption. Difference obtained in weight taken before and after clot lysis was expressed as percentage of clot lysis. Percentage of clot lysis was determined from below formula.

$\%$ of clot lysis $=($ weight of released clot/clot weight $) \times 100$

\subsection{Qualitative Sreening of Phytochemicals}

One gram of the methanol extract of mussaenda roxburghii was dissolved in $100 \mathrm{ml}$ of methanol and was subjected to preliminary phytochemical screenings for determining nature of phytoconstituents ${ }^{[13-15]}$. A small portion of the dry extract was used for the phytochemical tests for compounds which includes carbohydrate, tannins, flavonoids, alkaloids, saponins, steroids, resins, and glycoside in accordance with the methods of with little modifications. All test procedure for chemical groups described ${ }^{[16]}$. We identified several compound in table-9.

\section{(i). Test for Carbohydrate}

\section{(a). Molisch's Test}

$2 \mathrm{ml}$ of an aqueous extract of the plant material in a test tube have to take + then have to add 2 drops of freshly prepared molisch's reagent + mixed thoroughly + allowed 2 $\mathrm{ml}$ of conc. Sulphuric acid to flow down the side of the inclined test tube. So that acid forms a layer beneath the aqueous solution. A red or reddish violet ring will form at the junction of the 2 layers. On standing or shakeing a dark purple solution will form. After diluted with $5 \mathrm{ml}$ of water a dull violet precipitate will form.

\section{(b). Benedict Test}

$0.5 \mathrm{ml}$ of an aqueous extracts of the plant material + added $5 \mathrm{ml}$ of benedicts solution + boil for 5 minutes and allow cooling spontaneously. A red precipitate of cuprous oxide is formed in the presence of a reducing sugar.

\section{(c). Fehling's Test}

$2 \mathrm{ml}$ of an aqueous extract of the plant material + add $1 \mathrm{ml}$ of a mixture of equal volume of fehling's solutions $a \& b$. Boil for a few minutes. A red or brick red precipitate is formed if a reducing sugar is present. 


\section{(ii). Test for Alkaloids}

\begin{tabular}{|c|c|c|}
\hline test name & experimentation & observation \\
\hline 1)mayer's test & $\begin{array}{l}1 \mathrm{ml} \text { of filtrate }+ \text { few } \\
\text { drops of mayer's } \\
\text { reagent. }\end{array}$ & $\begin{array}{l}\text { White or cremy white } \\
\text { precipitate indicates the } \\
\text { presence of alkaloids. }\end{array}$ \\
\hline 2)wagner's test & $\begin{array}{l}1 \mathrm{ml} \text { of filtrate+ few } \\
\text { drops of wagnar's } \\
\text { reagent. }\end{array}$ & $\begin{array}{l}\text { Brown or deep brown ppt } \\
\text { indicates the presence of } \\
\text { alkaloids. }\end{array}$ \\
\hline 3)hager's test & $\begin{array}{l}1 \mathrm{ml} \text { of filtrate }+ \text { few } \\
\text { drops of hager's reagent. }\end{array}$ & $\begin{array}{l}\text { Yellow crystalline } \\
\text { precipitate indicates the } \\
\text { presence of alkaloids }\end{array}$ \\
\hline 4)tannic acid test & $\begin{array}{l}1 \mathrm{ml} \text { of filtrate }+ \text { few } \\
\text { drops of tannic acid } \\
\text { reagent. }\end{array}$ & $\begin{array}{l}\text { Dirty white or black } \\
\text { precipitate } \\
\text { Indicates the presence of } \\
\text { alkaloids. }\end{array}$ \\
\hline
\end{tabular}

\begin{tabular}{|c|c|c|}
\hline test name & experimentation & observation \\
\hline $\begin{array}{l}\text { General test } \\
\text { for glycoside }\end{array}$ & $\begin{array}{l}\text { A small amount of extract } \\
\text { dissolved in small amount of } \\
\text { water }+ \text { few drops of aqueous } \\
\text { sodium hydroxide solution }\end{array}$ & $\begin{array}{l}\text { Presence of yellow } \\
\text { colour indicates the } \\
\text { presence of } \\
\text { glycosides. }\end{array}$ \\
\hline
\end{tabular}

(iv). Test for Steroids

\begin{tabular}{lll}
\hline test name & experimentation & observation \\
\hline $\begin{array}{l}\text { Libermann- } \\
\text { burchard's test }\end{array}$ & $\begin{array}{l}2 \mathrm{ml} \text { of a chloroform } \\
\text { extract }+2 \mathrm{ml} \text { of acetic } \\
\text { anhydride }+1 \mathrm{ml} \text { of } \\
\text { conc. Sulphuric acid }\end{array}$ & $\begin{array}{l}\text { A greenish colour will } \\
\text { form at the junction of } 2 \\
\text { layers, which turns blue } \\
\text { on standing, indicates } \\
\text { presence of steroids. }\end{array}$ \\
$\begin{array}{l}2 \mathrm{ml} \text { of a chloroform } \\
\text { extract of the plant } \\
\text { material +1 ml of conc. } \\
\text { Sulphuric acid from the } \\
\text { side of the test tube. }\end{array}$ & $\begin{array}{l}\text { A red color is produced } \\
\text { in the chioroform layer if } \\
\text { steroids are present. }\end{array}$ \\
\hline
\end{tabular}

\section{(v). Test for Tannins}

\begin{tabular}{|c|c|c|}
\hline Test name & Experimentation & Observation \\
\hline $\begin{array}{l}\text { 1)ferric } \\
\text { chlorides } \\
\text { test }\end{array}$ & $\begin{array}{l}5 \mathrm{ml} \text { of alcoholic extract } \\
\text { solution }+1 \mathrm{ml} 5 \% \text { ferric } \\
\text { chloride solution }\end{array}$ & $\begin{array}{l}\text { A blue, blue black green or } \\
\text { blue green colour or } \\
\text { precipitation is produced in } \\
\text { the presence of tannins. On } \\
\text { addition of a few ml of } \\
\text { dilute sulphuric acid the } \\
\text { colour disappeares followed } \\
\text { by the formation of a } \\
\text { yellowish brown ppt. }\end{array}$ \\
\hline $\begin{array}{l}\text { 2)lead } \\
\text { acetate test }\end{array}$ & $\begin{array}{l}5 \mathrm{ml} \text { of an aqueous extract } \\
\text { of the plant material+ few } \\
\text { drops of a } 1 \% \text { solution of } \\
\text { lead acetate. }\end{array}$ & $\begin{array}{l}\text { A yellow or red ppt is } \\
\text { formed. }\end{array}$ \\
\hline $\begin{array}{l}\text { 3)potassium } \\
\text { dichromate } \\
\text { test }\end{array}$ & $\begin{array}{l}5 \mathrm{ml} \text { of alcoholic extract of } \\
\text { plant material }+1 \mathrm{ml} 10 \% \\
\text { potassium dichromate } \\
\text { solution }\end{array}$ & $\begin{array}{l}\text { Yellow orange ppt indicates } \\
\text { the presence of tannins. }\end{array}$ \\
\hline
\end{tabular}

\section{(vi). Test for Resins}

\begin{tabular}{lll}
\hline Test name & Experimentation & Observation \\
\hline \multirow{3}{*}{ General test } & $\begin{array}{l}\text { Using gentle heat, have to } \\
\text { dissolve a small amount of } \\
\text { chloroformic or ethanolic extract } \\
\text { of the plant material in } 5 \text { to } 10 \mathrm{ml} \\
\text { of acetic anhydride. Cool \& have } \\
\text { to add } 0.05 \mathrm{ml} \text { of sulphuric acid. }\end{array}$ & $\begin{array}{l}\text { If resin are present, a } \\
\text { bright purplish red } \\
\text { colour,rapidly } \\
\text { changing to violet,is } \\
\text { produced. }\end{array}$ \\
\hline
\end{tabular}

\section{(vii). Test for Flavonoids}

\begin{tabular}{lll}
\hline Test name & Experimentation & Observation \\
\hline $\begin{array}{l}\text { Conc. Hcl and } \\
\text { alcoholic test }\end{array}$ & $\begin{array}{l}\text { Small amount of } \\
\text { alcoholic extract of the } \\
\text { plant material + few } \\
\text { drops of conc. Hcl }\end{array}$ & $\begin{array}{l}\text { Immediate development } \\
\text { of red color indicates the } \\
\text { presence of flavonoids. }\end{array}$ \\
\hline
\end{tabular}

\begin{tabular}{|c|c|c|}
\hline Test name & Experimentation & Observation \\
\hline $\begin{array}{l}\text { Shake test (aq. } \\
\text { Solution froth } \\
\text { test) }\end{array}$ & $\begin{array}{l}\text { Boil about } 0.1 \text { gm of the } \\
\text { powdered plant material with } \\
10 \mathrm{ml} \text { of water for } 3-5 \text { minutes } \\
+ \text { filter+after cooling dilute } 5 \\
\text { ml of the filtrate with water } \\
\text { and shake vigorously. }\end{array}$ & $\begin{array}{l}\text { Production of a } \\
\text { persistent frothing } \\
\text { ( which remains stable } \\
\text { on heating ) indicates } \\
\text { the presence of } \\
\text { saponins. }\end{array}$ \\
\hline
\end{tabular}

\subsection{Statistical Analysis}

The experimental results were expressed as the mean \pm standard deviation (sd). Statistical significance of the mean mortality at each concentration was analyzed using one-way analysis of variance (anova) and compared using duncan's multiple range tests. Values of $\mathrm{p} \leq 0.05$ were taken to be statistically significant.

\section{Results and Discussion}

Denaturation of proteins is a well-documented cause of inflammation. Salicylic acid, phenylbutazone, flufenamic acid (anti-inflammatory drugs) etc, have shown dose dependent ability to thermally induced protein denaturation ${ }^{[8]}$ Ability of extracts to inhibit protein denaturation was studied to indentify mechanism of the anti-inflammatory activity. Both the extracts were effective in inhibiting heat induced albumin denaturation at different concentrations as shown in figure-1. In the present study for the in-vitro antiinflammatory test, the crude methanolic extracts of mussaenda roxburghii hook. Showed mean inhibition of protein denaturation $17.399 \pm 0.01937$. Whereas, for asa it was found to be $42.491 \pm 0.00698$. The ability of methanol extract of leaves of $m$. Roxburghii to inhibit thermal and hypotonic protein denaturation was found to be less significant than the positive acetyl salicylic acid.

Addition of $100 \mathrm{ul}$ of streptokinase, a positive control (1500000 i.u) to the clots along with 90 minutes of incubation at $37{ }^{\circ} \mathrm{c}$, exhibit $69.35 \%$ clot lysis. Clots when treated with $100 \mu \mathrm{l}$ sterile distilled water (negative control) showed only negligible clot lysis (6.23\%). After treatment of clot with $m$. Roxburghii (mother methanolic extract), $m$. Roxburghii (dcm extract ,fraction 1), m. Roxburghii (ethyl acetate extract, fraction 2), m. Roxburghii ( residual methanolic extract, fraction 3), $m$. Roxburghii (methanolic extract of leaves) $30.56 \%, 27.6096 \%, 46.35 \%, 26.02 \%, 49.90 \%$ clot lysis were observed respectively and mean of percentage of clot lysis was more than water. Results are shown in figure-2.

The result obtained in the present investigation phytochemicals screening of the methanol extract of leaves of $m$. Roxburghii revealed that the crude extract contained 
flavonoids, saponins, steroids, tannins and triterpinoids, terpinoids, cardiac glycosides and anthraquinones (table-1). $M$. Roxburghii leaves can also have various medicinal values such as anti-inflammatory, membrane stabilizing and thrombolytic activity. The presence of flavonoids exhibit significance anticancer, cardioprotective, anti-microbial activity may demonstrate gram-positive, gram-negative as well as fungi also. Among of the microorganisms are resistance to several drugseach though, this is only a preliminary study of the occurrence of certain properties of $m$ Roxburghii leaves an in-depth study will provide a good concerted base of all the phytochemicals and several pharmacological functions mention above.

Table 1. Chemical group test result for Mussaenda roxburghii leaves parts.

\begin{tabular}{lll}
\hline Examixanation & Test performed & Result for m. roxburghii leaves \\
\hline \multirow{3}{*}{ 1)Carbohydrate } & 1)Molisch's test (test for Gum) & $(+)$ ve \\
& 2)Benedict test (test for Reducing sugar) & $(-)$ ve \\
& 3)Fehling's test (test for Reducing sugar) & $(-) \mathrm{ve}$ \\
& 1)Mayers test & $(+) \mathrm{ve}$ \\
2)Alkaloids & 2)Wagner's test & $(+) \mathrm{ve}$ \\
& 3)Hager's test & $(+) \mathrm{ve}$ \\
& 4)Tannic acid test & $(+) \mathrm{ve}$ \\
3)Tannins & 1) Ferric chloride test & $(+) \mathrm{ve}$ \\
& 2)Lead acetate & $(-) \mathrm{ve}$ \\
& 3)Potassium dichromate test & $(+) \mathrm{ve}$ \\
4)Resins & & $(-) \mathrm{ve}$ \\
5)Flavonoids & Conc. HCl \& Alcoholic test. & $(-) \mathrm{ve}$ \\
6)Saponins & Shake test(aq. Solution froth test. & $(-) \mathrm{ve}$ \\
7)Glycosides & 1) General test & $(-) \mathrm{ve}$ \\
9)Steroids & 1)Liebermann Barchards test & $(-) \mathrm{ve}$ \\
& 2)Salkowski's test & $(-) \mathrm{ve}$ \\
\hline
\end{tabular}

$(+)=$ present and $(-)=$ absence

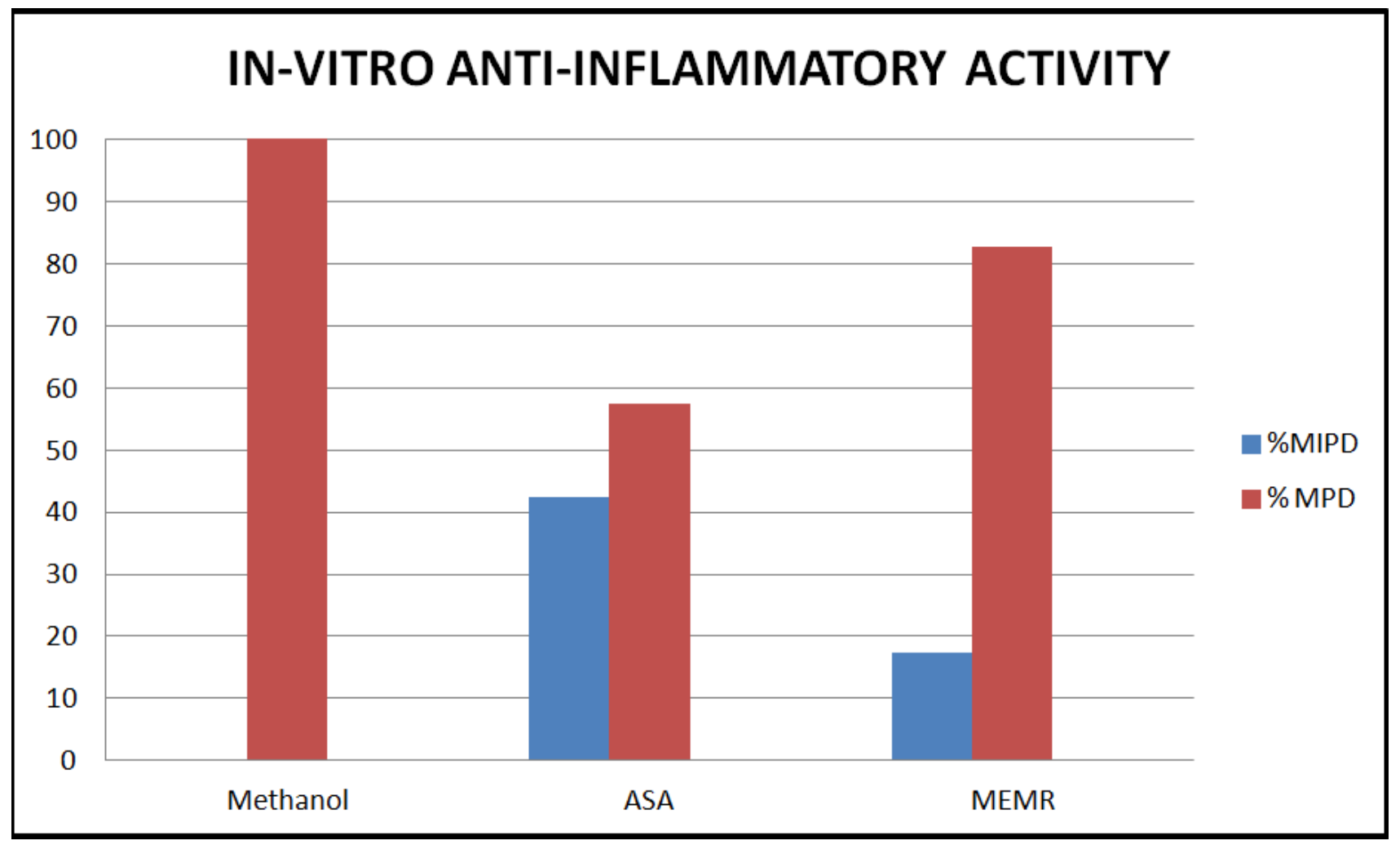

Figure 1. Mean inhibition of protein denaturation (\% MIPD) and Mean protein denaturation (\%MPD) VS treatment groups. Here, ASA=Acetyl salicylic acid, $M E M R=$ Methanolic extract of Mussaenda roxburghii. 


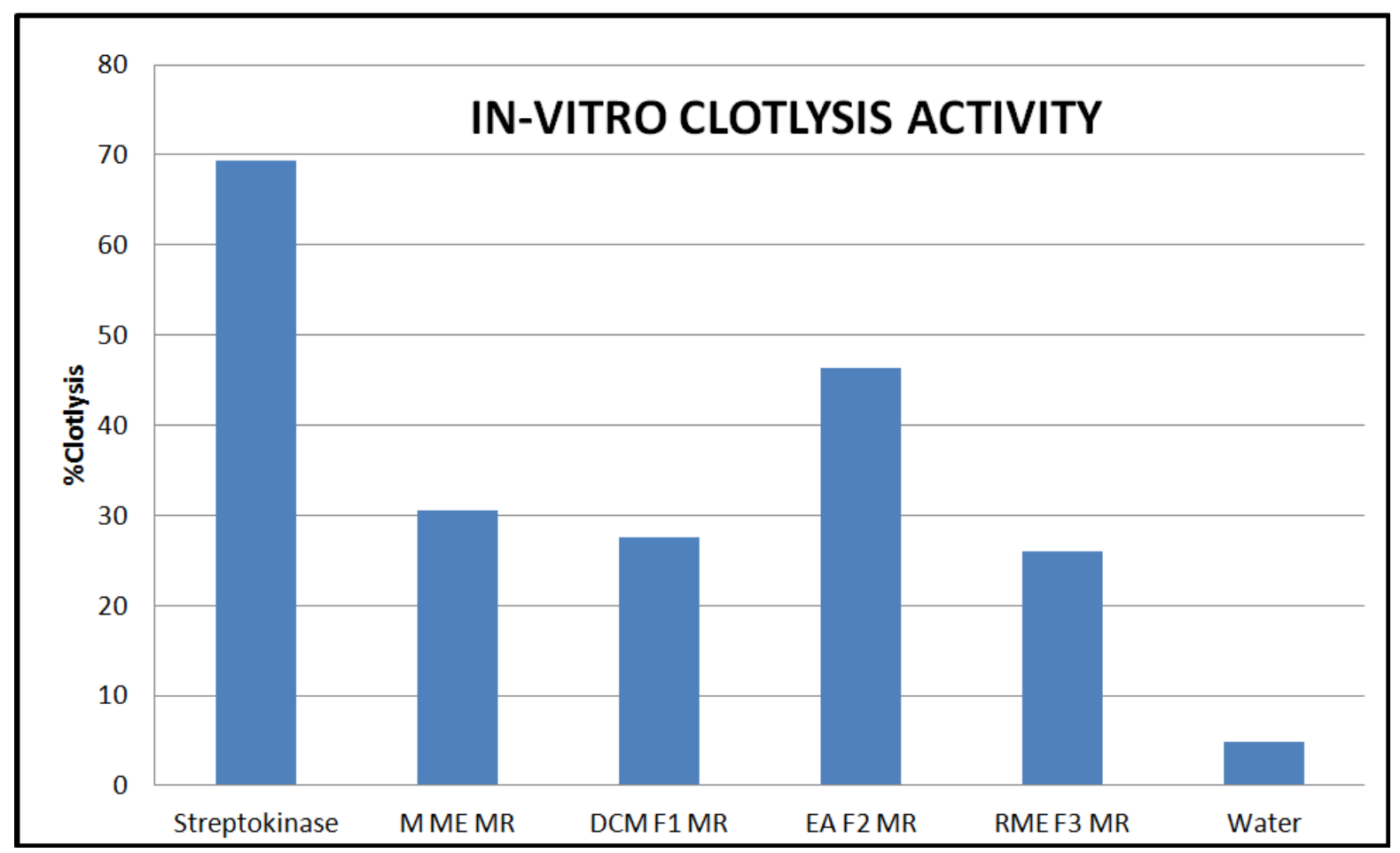

Figure 2.\% clotlysis of different extracts of Mussaenda roxburghii (Leaves).

Here, MMEMR= Mother methanolic extract of $M$. roxburghii, DCM F1 MR= DCM extract (fraction 1) of $M$. roxburghii, EA F2 MR=Ethyl acetate extract (fraction2) of M. roxburghii, RME F3 MR= Residual methanolic extract (fraction3) of M. roxburghii.

\section{Conclusion}

In the present study, we have found that most of the biologically active phytochemicals were present in the methanolic extract of $m$. Roxburghii leaves. This is only a preliminary study and to make final comment the extract should thoroughly investigated phytochemically and pharmacologically to exploit their medicinal and pharmaceutical potentialities.

\section{Acknowledgement}

We are acknowledge to north south university and progati medical institute for provide us required facilities to complete this work.

\section{References}

[1] Farnsworth nr, akerele o, bingel as, soejarta dd, eno z. Medicinal plants in therap. World health organ 1985; 63: 96581.

[2] Saha j, sarkar pk, chattopadhyay s. 2011. A survey of ethnomedicinal plants of darjeeling hills for their antimicrobial and antioxidant activities. Ind $\mathrm{j}$ nat prod res 2 : 479 - 492.

[3] Patil sa, joshi vg. 2011. Evaluation of antibacrerial and wound healing activity of leaves of mussaenda frondosa linn. Int $\mathrm{j}$ res pharmac biomed sc 2: $147-154$.
[4] Das hb, majumdar k, datta bk, ray d. 2009. Ethnobotanical uses of some medicinal plants by tripuri and reang tribes of tripura. Nat prod rad 8: $172-180$.

[5] Rahman ma. 2010. Indigenous knowledge of herbal medicines in bangladesh and treatment of skin diseases by tribal communities of the hill tracts districts. Bangladesh $\mathrm{j}$ bot 39: $169-177$

[6] Chandra du, ghosh r, chowdhury s, dinda b. 2012. New iridoid from aerial parts of mussaenda roxburghii. Nat prod commun 7: $1-2$.

[7] Van wagenen bc, larsen $r$, cardellina jh, ran dazzo d, lidert zc and swithenbank c: ulosantoin (1993) a potent insecticide from the sponge ulosaruetzleri. Journal of organic chemistry 58: 335-337.

[8] Mizushima $y$ and kobayashi $m$. Interaction of antiinflammatory drugs with serum preoteins, especially with some biologically active proteins. $J$ of pharma pharmacol. 1968; 20:169-173.

[9] Reyad-ul-ferdous m, alam tt, islam ma, khan mzi, tasnim f, et al (2014) ex-vivo cardioprotective and cytotoxic screening of fruits of parmentiera ereifera seem. Biol med 6: 219. Doi: 10.4172/0974-8369.1000219.

[10] Md. Reyad-ul-ferdous, sayma akhter, md. Zahirul islam khan, md. Eshak khan, md. Atiqul islam, md. Sharif ullah. Ex-vivo anti-inflammatory and antimicrobial activities of the leaves of bauhinia acuminata. American journal of life sciences. Vol. 2, no. 5, 2014, pp. 267-270. Doi: 10.11648/j.ajls.20140205.13.

[11] Daginawala hf, prasad s, kashyap rs, deopujari jy, purohit hj and taori gm (2006) development of an in vitro model to study clot lysis activity of thrombolytic drugs. Thrombosis journal 4: 14 . 
[12] Kawsar mh, sikder ma, rana ms, nimmi i and rashid ma (2011) studies of thrombolytic and cytotoxic properties of two asteraceous plants of bangladesh. Bangladesh pharmaceutical journal 14: 103-106.

[13] Md. Reyad-ul-ferdous, nasir uddin, d.m. shamim shahjahan, mosharaf hossen, md. Saiful islam arman, ariful islam. Preliminaryin-vitro potential phytochemicals investigation of barks of ravenala madagascariensis sonnerat. Wjpps, 2014; 3(9), 1418-1423.
[14] Egwaikhide, p.a., s.o. okeniyi and c.e. gimba, 2007. Screening for antimicrobial activity and phytochemical constituents of some nigerian medicinal plants. Adv. Biological res., 1: 155158.

[15] Harborne, j.b. phytochemical methods. A guide to modern techniques of plant analysis. 3rd edn., new york; chapman and hall int ed.1998.

[16] Gani a. Methods of screening, practical phytochemistry, $2^{\text {nd }}$ edn, dhaka:chaya prokashoni; 2007.p. 12-17. 